\title{
Series
}

\section{空から見る日本の地すべり地形シリーズー22ー Aerial watching of landslides in Japan -22-}

\section{山形県肘折カルデラ北方の銅山川地すべり}

Dozangawa Landslide located to the north of Hijiori Caldera of an active volcano in Yamagata Pref., northeast Japan

八木浩司 Hiroshi YAGI/山形大学 Yamagata University

井口 隆 Takashi INOKUCHI/防災科学技術研究所 National Research Institute for Earth Science and Disaster Prevention

キーワード：肘折カルデラ, 火砕流堆積面, 大規模地すべり, 滑落崖・凹地列・尾根状地形群

Key words : Hijiori caldera, depositional surface of pyrocrastic flow, large scale landslide, scarp-depression-ridge system

\section{1. 銅山川地すべりの概要}

山形県最上郡大蔵村に位置する銅山川地すべりは，月 山東面から流れ出る銅山川が时折カルデラを貫流し，さ らに $2 \mathrm{~km}$ 下ったその右岸及びその周辺に発達する大規 模地すべりである（図-1，写真 -1 ，口絵 $-1 ， 2 ， 3$ )。

銅山川地すべりは，下流側から南山，寒風亩，および 湯ノ台の 3 地区から構成されその直轄地すべり防止指定 区域は328haに及ぶ。南山地区と寒風田地区は銅山川支 流の泥水沢で境され，湯ノ台は古水川（赤谷川支流）沿 いにも分布する。

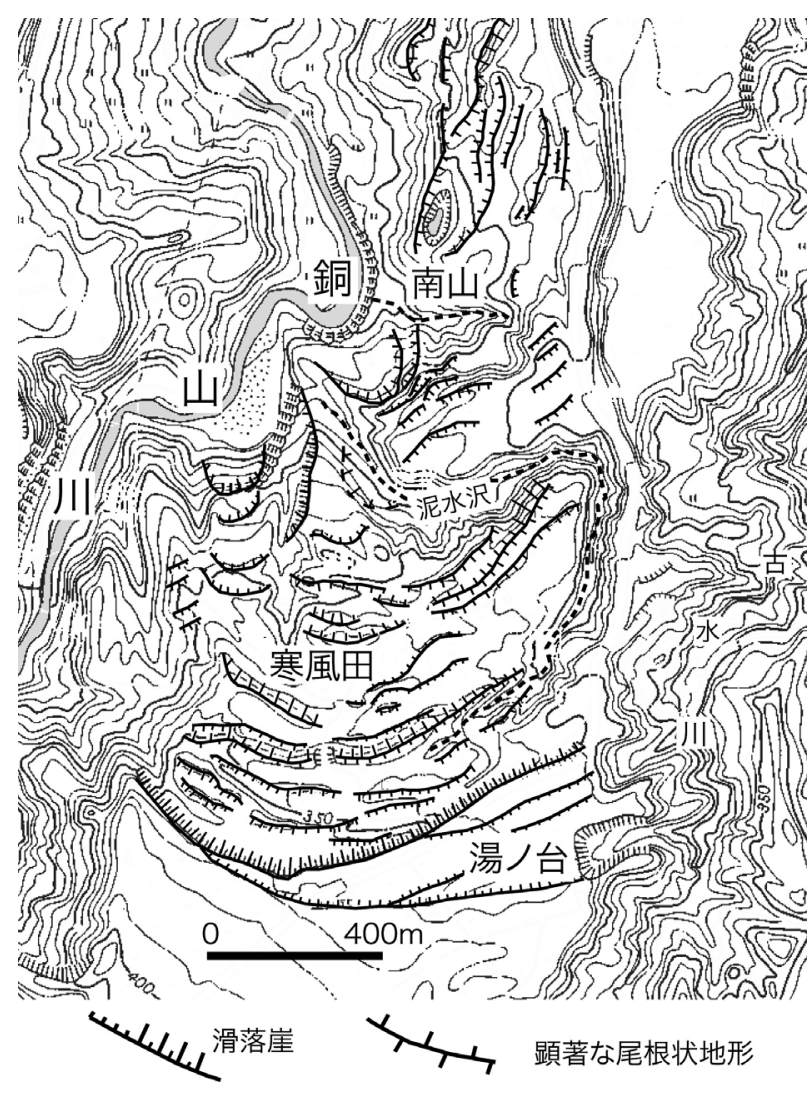

图一 1 銅山川地すべりの地形的特徵

\section{2. 火砕流台地を切る滑落崖・二次滑落崖群}

寒風田地区（面積約78ha）には, 湯ノ台と呼ばれる 时折カルデラ起源の火挽流堆積面（肘折火砕流: 約 1 万 年前)，いわゆるシラス台地を切る北〜北北西に開いた 弧状の滑落崖が発達している(図-1, 写真- 2 )。そし て主滑落崖前面（北側）に移動体が二次滑落崖によって 分離され, 複数の並行する弧状の滑落崖・凹地列・尾根 状地形群をなしている。南山地区では, 泥水沢に沿って 北東一南西走向の滑落崖と凹地列が発達するが，沢を挟 んでさらに北部では南北性の滑落崖・凹地列・尾根状地 形群が卓越するようになる。湯ノ台地区は，火砕流堆積 面を比高 $2-3 \mathrm{~m}$ のやや直線的な低崖によって変位を受 けている。銅山川に沿った攻撃斜面上部では，上述の構 造を切って局所的な地すべり活動の痕跡が読み取れる。

本地すべりに対しては，山形県による地すべり防止対 策事業が1952年から進められてきた。1948年以降撮影さ れた複数時期の空中写真判読の比較から1966年から地す ベり活動が顕在化したとの報告がある（林業土木コンサ ルタンツ，2000）。また1948年撮影の空中写真でも弧状 の尾根。凹地列群は明暸で, 1910 年 (明治43年) 発行 $1 / 5$ 万地形図上でも同様な地形が認められることから（図-

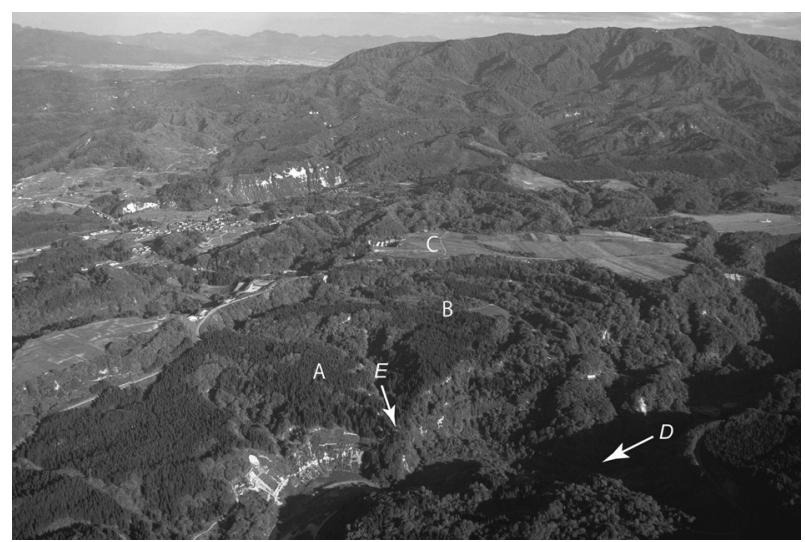

写真ー 1 北西上空から見た銅山川地すべりとその周辺 $A$ : 南山地区, B : 寒風田地区, $C$ : 湯ノ台地区 $\mathrm{E}:$ 銅山川, D : 泥水沢 


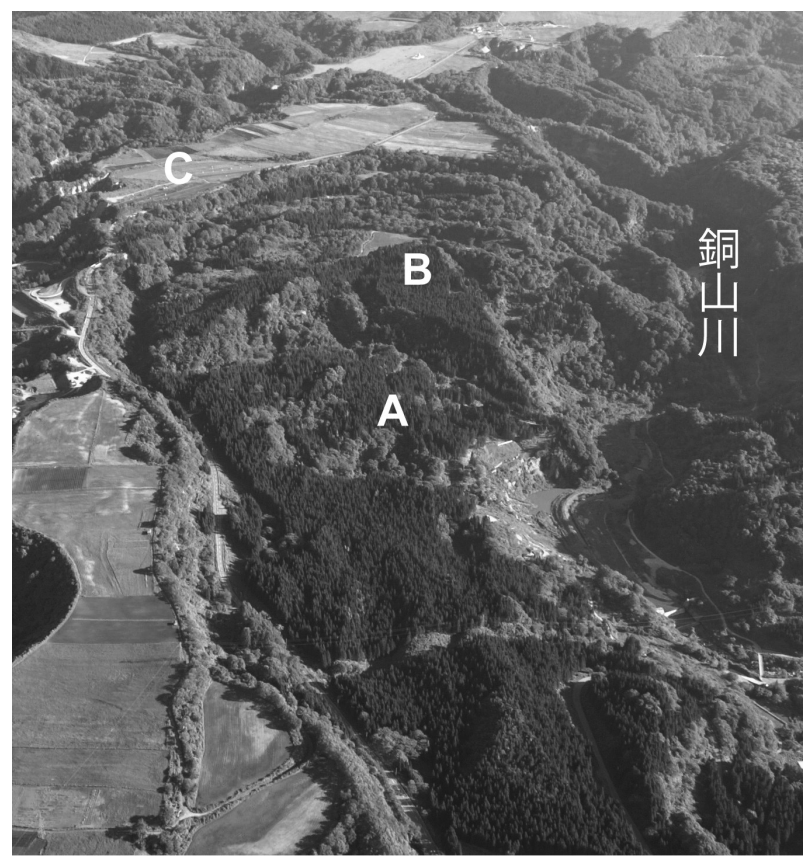

写真一 2 北側上空から見た銅山川地すべり $A$ : 南山地区, B : 寒風田地区, $C$ : 湯ノ台地区

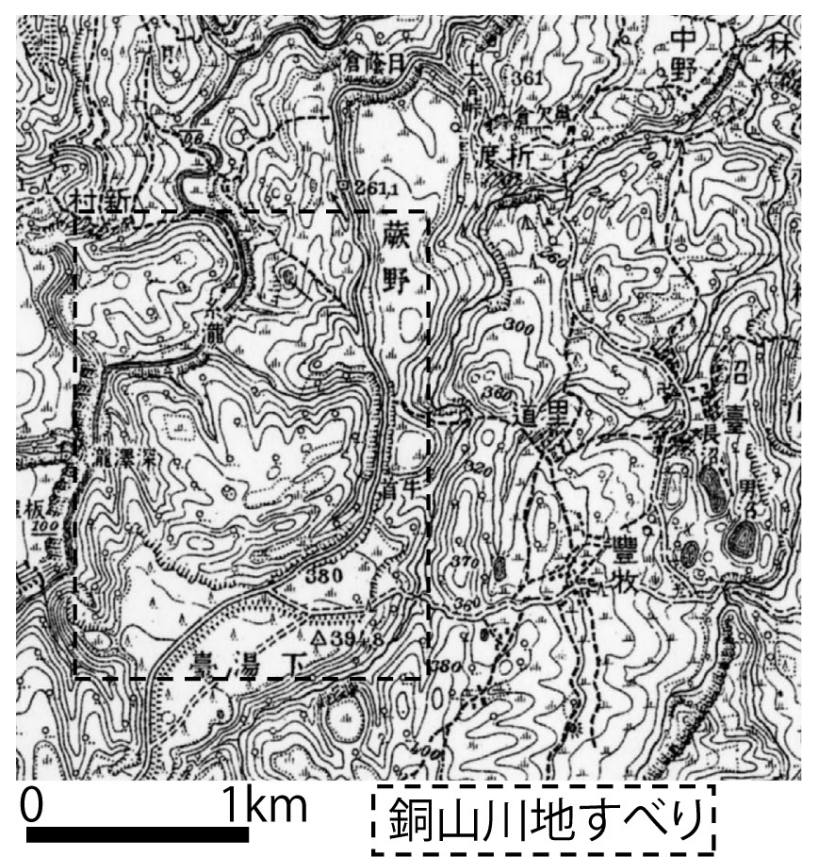

図ー2 明治末期の銅山川地すべり周辺の地形図 陸地測量部明治43年測量 $1 / 5$ 万地形図仙台 13 号月山
2 )，銅山川地すべりの概形は近世以前には既に形成さ れていたものと考えられる。

\section{3. 近年の地すべり活動}

1996年の融雪期に，上部の湯ノ台に陥没帯の形成を伴 う130haに及ぶ地すべり活動がおこった。その変位は, 最大 $72 \mathrm{~mm} / \mathrm{day}$ の速度で, 冠頂部に沈下量 $3 \mathrm{~m}$ 程度, 幅 $200 \mathrm{~m}$ の陥没帯を東西に $600 \mathrm{~m}$ に亘って形成した。また移 動体は，最大傾斜方向である北北西の銅山川方向への動 きを示さず，一旦北北東方向への動きを示したのち南山 地区で西に捻れるような動きを示している（東北森林管 理局，2011）。このような地形の最大傾斜方向に必ずし も一致しない逆時計回りの移動は, 本地すべり周辺の地 質構造や地すべり移動体の地下構造に影響されてもの考 えられている（山科ほか, 2004）。すなわち, 銅山川地 すべり周辺には, 上位より肘折火砕流, 鮮新統・野口層 および中新統・古口層が分布し，すべり面は東へ 8 $10^{\circ}$ 傾斜する古口層の層理面に沿って発達している。こ のような地質構造に沿った流れ盤的な動きと地形効果の 重合現象として，西に念れるような動きを示しているの である。なお，本地すべり周辺の肘折火砕流は，厚さ 130 $\mathrm{m}$ にも及ぶが，地下水供給源としての役割を果たしてい ると考えられている。現在東北森林管理局による排水卜 ンネル施工などの地すべり対策事業が進められている。

\section{引用文献}

1 ）林業土木コンサルタンツ（2000）：銅山川地区直轄地すべり防 止事業検討委員会報告書. p129, 東北森林管理局

2 ) 東北森林管理局 (2011)：直轄地すべり防止事業「銅山川地区」 技術検討会資料. p 41, 東北森林管理局, http://www.rinya. maff.go.jp/tohoku/apply/publicsale/chisandouzankaya.html, 参照日 2012 年 2 月 14 日

3 ) 山科真一 - 山崎勉 $\cdot$ 熊井直也 $\cdot$ 川崎則秋 (2004) : 火砕流台 地で発生した大規模地すべり一銅山川地すべりの発生機構 - . 日本地すべり学会第43回研究発表会講演集, pp213-216. （原稿受付2012年 2 月16日，原稿受理2012年 2 月27日） 